\title{
NOTE
}

\section{Accumulation of tetrodotoxin in marine sediment}

\author{
K. Kogure, H. K. Do, E. V. Thuesen, K. Nanba, K. Ohwada, U. Simidu
}

Ocean Research Institute, University of Tokyo, Minamidai, Nakano, Tokyo 164, Japan

\begin{abstract}
Tetrodotoxin (TTX) was accumulated at high concentrations in sediment samples from 2 inner water stations and 1 deep-sea station in the western Pacific off the coast of Japan. TTX was identified using tissue culture bioassay and HPLC. It is suggested that bacteria inhabiting the sediment are responsible for the production of toxin. The widespread occurrence of TTX in marine sediments is predicted; such large concentrations of TTX may affect animals inhabiting these sediments.
\end{abstract}

Tetrodotoxin (TTX), known as 'puffer fish toxin', is a potent neurotoxin which blocks the sodium channel of neuronal cells. It has recently been established that this toxin is present in diverse groups of animals, especially those of marine environments (Mosher \& Fuhrman 1984, Thuesen et al. 1988). Although mechanisms of TTX accumulation are still obscure, the widespread occurrence of marine bacteria which produce tetrodotoxin (Simidu et al. 1987) suggests that bacteria are responsible for the production of TTX in natural environments. Since marine sediments generally contain large bacterial populations, we investigated the presence of TTX or related sodium channel blocking agents in these sediments and consider the possible accumulation of TTX in the environment. Sediment samples, including one from $4033 \mathrm{~m}$ depth, were analyzed by a newly developed tissue culture assay method (Kogure et al. 1988) and by high performance liquid chromatography (HPLC).

Sediment samples were taken using a Phleger corer from 2 stations in Tokyo Bay (Stns A and B), which is highly polluted, and 1 station in an open ocean deep area (Stn C), during the KT-87-17 cruise of the RV 'Tansei Maru', Ocean Research Institute, University of Tokyo, in November 1987 (Fig. 1). Sediment samples were separated into layers on board immediately after collection. A portion of them were used to enumerate heterotrophic bacteria, while the rest were kept at $-20^{\circ} \mathrm{C}$ until toxin extraction in the laboratory. Bacterial colonies appearing on ZoBell's 2216E agar plates were counted after 3 wk incubation at $20^{\circ} \mathrm{C}$. For the extraction of toxins, sediment samples were thawed, mixed with 10 times their volume of $0.1 \%$ acetic acid, and boiled for $20 \mathrm{~min}$. After centrifugation at $25000 \times \mathrm{g}$, the supernatant was freeze-dried and reconstituted in a small amount of distilled water. Samples for HPLC analysis were further purified using SEP-PAK $\mathrm{C}_{18}$ cartridges (Waters Associates).

Tissue culture bioassay (Kogure et al. 1988) was used for the detection and quantitative measurement of sodium channel blocking toxin in the samples. In brief, the alkaloid toxin veratridine causes sodium influx in the mouse neuroblastoma cell line Neuro 2A (ATCC, CCL 131), when the function of $\mathrm{Na}^{+}-\mathrm{K}^{+}$ATPase is inhibiled by oudbain. This causes cellular swelling and subsequent death; TTX and similar sodium channel blocking agents counteract this effect and enable cells to continue growing. The ratio of living to dead cells can be used to estimate the concentration of toxin in

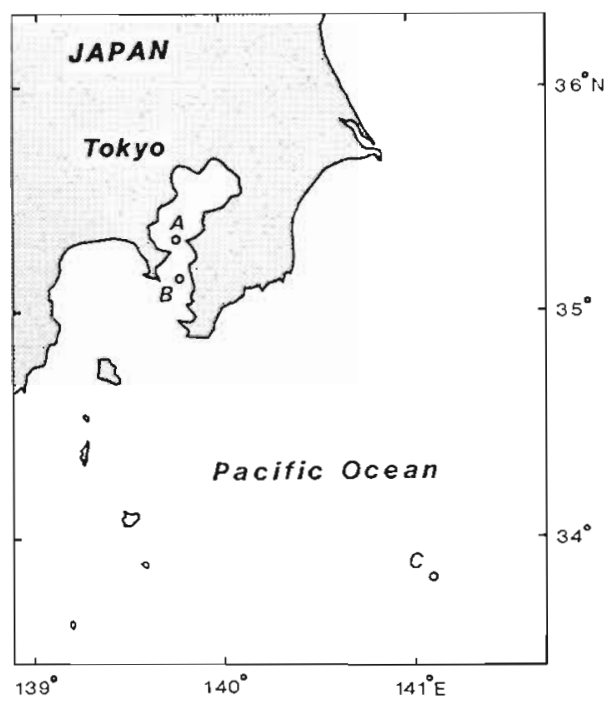

Fig. 1 Sampling locations 
the sample. Samples were further analyzed by ionpaired reverse-phase HPLC to identify sodium channel blocking agents to a JASCO Tri Rotar-VI HPLC system with a $6 \times 300 \mathrm{~mm}$ silica ODS column (Senshu Scientific Co.) following methods and conditions described previously (Nagashima et al. 1987). Fluorescence was detected at $381 \mathrm{~nm}$ excitation and $505 \mathrm{~nm}$ emission on a Hitachi F1000 fluorescence spectrophotometer. TTX (Sigma) was used as a standard for both the cell culture bioassay and HPLC.

Table 1 shows the estimated concentrations of sodium channel blockers in mud samples. Concentrations are expressed as equivalent to TTX. The toxin

Table 1. Concentration of tetrodotoxin and numbers of heterotrophic bacteria in marine sediment. (CFU: colonyforming units)

\begin{tabular}{|c|c|c|c|c|}
\hline Station & $\begin{array}{l}\text { Depth } \\
\text { (m) }\end{array}$ & $\begin{array}{l}\text { Layer } \\
\text { (cm) }\end{array}$ & $\begin{array}{c}\text { TTX } \\
\left.\text { (ng } \mathrm{g}^{-1} \mathrm{mud}\right)\end{array}$ & $\begin{array}{l}\text { Bacterial no. } \\
\text { (CFUg }{ }^{-1} \mathrm{mud} \text { ) }\end{array}$ \\
\hline A & 21 & $\begin{array}{c}0-3 \\
3-6 \\
6-11 \\
11-17\end{array}$ & $\begin{array}{l}57 \\
38 \\
37 \\
41\end{array}$ & $\begin{array}{c}1.8 \times 10^{6} \\
1.3 \times 10^{6} \\
- \\
-\end{array}$ \\
\hline B & 82 & $\begin{array}{c}0-3 \\
3-6 \\
11-17\end{array}$ & $\begin{array}{l}30 \\
27 \\
54\end{array}$ & $\begin{array}{l}1.8 \times 10^{6} \\
8.5 \times 10^{5} \\
1.0 \times 10^{5}\end{array}$ \\
\hline$C$ & 4033 & $\begin{array}{c}0-2 \\
2-5 \\
5-8 \\
8-11 \\
15-18\end{array}$ & $\begin{array}{l}90 \\
40 \\
65 \\
37 \\
25\end{array}$ & $\begin{array}{l}3.3 \times 10^{4} \\
1.1 \times 10^{4} \\
5.5 \times 10^{3} \\
7.0 \times 10^{2} \\
5.5 \times 10^{2}\end{array}$ \\
\hline
\end{tabular}

was detected from all samples, regardless of sampling location or depth. There was no appreciable difference in concentration among the 3 stations tested. Table 1 also shows the numbers of heterotrophic bacteria. The numbers were smaller at $S \operatorname{tn} C$, probably due to lower organic concentrations and also the presence of barophilic and/or psychrophilic bacteria (Morita 1975, Yayanos et al. 1982) which might have died off during the incubation at atmospheric pressure at $20^{\circ} \mathrm{C}$. In sediment cores, both toxin and bacterial number tended to decrease with depth.

Fig. 2 shows the results of HPLC analysis of the deepsea sediment sample. The retention time of the peak in the sample was the same as that of the TTX standard. The peaks occurring within several minutes of the TTX peak in the sample are most likely TTX analogues (Nagashima et al. 1987). Similar elution profiles were also observed for the samples from Tokyo Bay. Toxin concentrations as estimated by tissue culture bioassay were in good agreement with the HPLC results. From

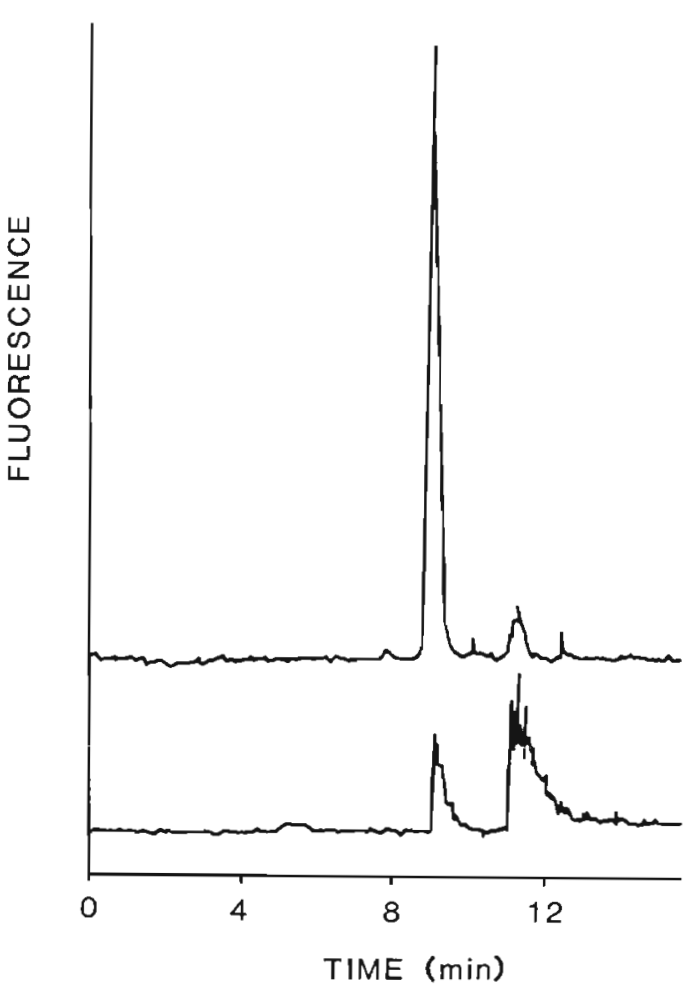

Fig. 2. HPLC analysis of tetrodotoxin (upper) and sediment sample (lower) from Stn C. The tetrodotoxin peak occurs at 9.2 min and peaks following within several minutes are tetro. dotoxin analogues

this analysis, we conclude that the sodium channel blocking neurotoxins in the sediment samples as detected by cell culture bioassay were TTX and most likely related TTX analogues. At present, however, the possibility of the presence of other types of neurotoxin is still not excluded. Further investigations on the chemical nature of other toxins are currently being undertaken.

As was shown by Simidu et al. (1987), TTX-producing bacteria are quite widespread in the marine environment, and it seems most reasonable to assume that the toxins were produced by bacteria living in the sediment. The concentrations of TTX in marine sediments were unexpectedly high, a few to $10 \mathrm{~g}$ of sediment containing a quantity sufficient to kill one mouse. These may even have been underestimates because of possible inefficient extraction procedures. At present, it is not clear in which sediment component the ITX is located. It may be in living or dead organisms, associated with abiotic materials, or both. TTX is expected to be very stable in the environment under conditions of low temperature and $\mathrm{pH}$ (Mosher 1986), and, once produced, may be able to remain in marine sediments for a long time without degradation if these conditions exist. 
It seems probable that sediment TTX may have some physiological effect on the deposit feeders, infauna and epifauna of the marine benthos, and some of these animals likely accumulate TTX. Thuesen et al. (1988) recently reported TTX as the primary toxic agent in the venom of chaetognaths - ubiquitous carnivores in the zooplankton. A similar role for TTX may also occur among benthic organisms

In conclusion, TTX was found to occur throughout marine sediments at rather high concentrations. TTX can no longer be regarded as an esoteric toxin whose distribution is restricted to certain groups of organisms. Further investigations on the origin, mechanism of accumulation, and physiological role are likely to lead to the establishment of a new concept for the role of this particular neurotoxin in nature.

Acknowledgements. We thank the captain, crew officer and scientists aboard the KT-87-17 cruise of the RV 'Tansei Maru'. This work was partly supported by the Nippon Life Science Foundation.

\section{LITERATURE CITED}

Kogure, K., Tamplin, M., Simidu, U., Colwell, R. R. (1988). A tissue culture bioassay for tetrodotoxin, saxitoxin and related toxins. Toxicon. 26: 191-197

Morita, R. (1975). Psychrophilic bacteria. Bact. Rev. 39: $144-167$

Mosher, H. S. (1986). The chemistry of tetrodotoxin. Ann. N. Y. Acad. Sci. 479: 32-43

Mosher, H. S., Fuhrman, F. A. (1984). Occurrence and origin of tetrodotoxin. In: Ragelis, E. P. (ed) Seafood toxins. Am. Chem. Soc., Washington, D.C., p. 333-344

Nagashima, Y., Maruyama, J., Noguchi, T., Hashimoto, K. (1987). Analysis of paralytic shellfish poison and tetrodotoxin by ion-pairing high performance liquid chromatography. Nippon Suisan Gakkaishi. 53: 819-823

Simidu, U., Noguchi, T., Hwang, D. F., Shida, Y., Hashimoto, K. (1987). Marine bacteria which produce tetrodotoxin. Appl. environ. Microbiol. 53: 1714-1715

Thuesen, E. V., Kogure, K. Hashimoto, K., Nemoto, T. (1988). Poison arrowworms: a tetrodotoxin in the marine phylum Chaetognatha. J. exp. mar. Biol. Ecol. (in press)

Yayanos, A. A., Dietz, A. S., Boxtel, R. V. (1982). Dependence of reproduction rate on pressure as a hallmark of deep-sea bacteria. Appl. environ. Microbiol. 44: 1356-1361

This note was presented by Professor S. Puiseux-Dao; it was accepted for printing on April 27, 1988 